\title{
GAMBARAN KEPRIBADIAN MEREK TERHADAP KEPUTUSAN PEMBELIAN PRODUK BEDAK TABUR PIXY DI INDONESIA
}

\author{
Diana Ani Kartika \\ Universitas Pendidikan Indonesia \\ dianaanikartika@student.upi.edu \\ Ratih Hurriyati \\ Universitas Pendidikan Indonesia \\ ratih@upi.edu \\ Girang Razati \\ Universitas Pendidikan Indonesia \\ girangrazati@upi.edu
}

\begin{abstract}
ABSTRAK
Tujuan - Tujuan penelitian ini adalah untuk mengetahui gambaran tingkat kepribadian merek dan keputusan pembelian pada konsumen yang membeli produkPixy di Indonesia.

Desain/metodologi/pendekatan - Desain penelitian ini adalah cross sectional method. Penelitian ini menggunakan pendekatan deskriptif dengan metode explanatory survey. Sebanyak 130 responden dipilih dengan menggunakan non-probability sampling. Sebuah kuesioner digunakan sebagai instrumen penelitian untuk mengumpulkan data dari responden. Teknik analisis yang digunakan adalah teknik deskriptif dengan menggunakan distribusi frekuensi

Temuan - Berdasarkan hasil penelitian mneggunakan analisis deskriptif, didapatkan hasil kepribadian merek berkategori baik, dan keputusan pembelian berkategori baik.

Orisinalitas/nilai - Perbedaan dalam penelitian ini terletak pada objek penelitian, waktu penelitian, alat ukur, literatur yang digunakan, teori yang digunakan dan hasil penelitian.
\end{abstract}

Kata Kunci: kepribadian merek dan keputusan pembelian.

Jenis Artikel: Studi Kasus

\begin{abstract}
Purpose - The purpose of this study is to see the description of the level of brand personality, and purchase decision in consumers of Pixy powder in Indonesia.

Design/methodology/approachh - The design of this study was cross sectional method. This research uses descriptive approach with explanatory survey method. The nurses analysis unit is 130 people. Data collection using questionnaire. The analysis technique used is descriptive technique by using frequency distribution

Findings - Based on the results of the research using descriptive analysis, the results obtained that brand personality in the high category, and purchase decision in the good category.

Originality/value - The differences in this study located on an object research, time research, a measuring instrument, literature that used, the theory that is used and the results of the study.
\end{abstract}

Keywords: brand personality, and purchase decision

Article Type : Research Paper 


\section{PENDAHULUAN}

Dunia bisnis di era globalisasi ini menjadi sebuah tantangan bagi setiap dunia usaha untuk meningkatkan kinerja dan kualitas bisnisnya agar dapat bertahan dalam persaingan seperti saat ini (Ratih \& Irna, 2008). Hal tersebut berlaku juga pada industri kosmetik. Para produsen dalam industri ini dituntut untuk melakukan inovasi bisnis yang baru agar dapat mengungguli para pesaing, dengan menghasilkan produk yang diinginkan dan dapat diterima oleh konsumen. Pada saat sekarang ini konsumen tidak lagi hanya mengharapkan kualitas yang tinggi dari suatu produk, tetapi juga manfaat yang akan mereka terima dari produk tersebut (Mulyadi \& Saktiawati, 2008b).

Perusahaan harus dapat mengetahui dan mengenal terlebih dahulu keinginan dari pelanggan lalu merumuskan keinginan dan kebutuhan konsumen, keputusan pembelian akan menjadi alasan penting untuk konsumen karena konsumen merasa percaya diri dalam pengambilan keputusan sejak mereka telah mendapatkan pengalaman pembelian terhadap suatu produk. Banyaknya inovasi dan variasi produk yang ditawarkan setiap perusahaan, membuat konsumen dihadapkan dengan banyaknya pilihan dan akan menjadikan pasar yang semakin kompetitif, sehingga berdampak pada keputusan pembelian.

Masalah keputusan pembelian yang menurun salah satunya terjadi pada industri kosmetik. Perusahaan kosmetik dalam negeri kalah bersaing dengan perusahaan kosmetik multinasional. Penguasaan pangsa pasar kosmetik sebanyak 70\% lari ke tangan asing, perusahaan lokal hanya kebagian sisanya (www.tirto.id). Produk kosmetik yang teregistrasi sebanyak 36.642 berasal dari produk lokal sebanyak 40,52\%, produk Asean sebesar $4.69 \%$, produk kosmetik dari Eropa sebanyak $28,58 \%$, dan negara lainnya sebesar $26,21 \%$. Data keseluruhan jika dijumlahkan maka produk asing menguasai pasar impor di Indonesia sebesar $59,48 \%$.

TABEL 1

DATA PRODUK KOSMETIK IMPOR DAN LOKAL

\begin{tabular}{|c|c|}
\hline $\begin{array}{c}\text { Asal } \\
\text { Produk }\end{array}$ & Persentase \\
\hline Lokal & $40,52 \%$, \\
\hline Asean & $4,69 \%$ \\
\hline Eropa & $28,58 \%$ \\
\hline Lainnya & $26,21 \%$ \\
\hline
\end{tabular}

Tingginya konsumen yang rata-rata berkelas menengah menjadi permasalahannya karena muncul sebuah perasaan bangga pada pemakai produkproduk asing dan perasaan gengsi bila memakai produk lokal (www.tirto.id). Persaingan pada bidang industri ini menjadikan salah satu peluang dan tantangan bagi perusahaan sebagai produsen untuk terus memproduksi produk yang berkualitas, bervariasi dan dapat bersaing dengan produkproduk impor serta untuk mempertahankan eksistensi perusahaannya di masa yang akan datang (Utama \& Amelia, 2009).

Perusahaan kosmetik di Indonesia, khususnya yang megeluarkan produk bedak padat diantaranya Pigeon, Marcks, Wardah dan Pixy. Beberapa produk kosmetik di Indonesia yang mengalami kenaikan dan penurunan dari tahun 2015 sampai tahun 2017 dimana produk merek kosmetik Pixy menurun setiap tahunnya dapat dilihat pada Gambar 1 berikut.

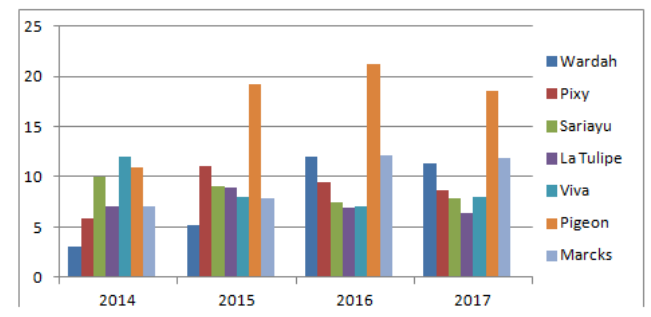

Sumber: Modifikasi dari www.topbrand-award.com

GAMBAR 1

\section{PENJUALAN BEDAK WAJAH KOSMETIK DI INDONESIA TAHUN 2015-2017}

Salah satu kategori produk dalam industri kosmetik adalah bedak tabur. Beberapa dasawarsa terakhir, industri ini diwarnai oleh beberapa persaingan yang tinggi, sehingga konsumen dihadapkan pada beberapa jenis bedak tabur dengan berbagai variasi merek, kemasan, harga serta kualitasnya.

Tabel 2 di bawah memperlihatkan perusahaan dan produk yang termasuk ke dalam industri kosmetik

TABEL 2

PERUSAHAAN DAN PRODUK BEDAK TABUR

\begin{tabular}{llllccc}
\hline \multirow{2}{*}{ Merek } & \multicolumn{3}{c}{ Tahun } & \multicolumn{3}{c}{ Peringkat } \\
\cline { 2 - 7 } & $\mathbf{2 0 1 5}$ & $\mathbf{2 0 1 6}$ & $\mathbf{2 0 1 7}$ & $\mathbf{2 0 1 5}$ & $\mathbf{2 0 1 6}$ & $\mathbf{2 0 1 7}$ \\
\hline Wardah & $13.9 \%$ & $15.5 \%$ & $17 \%$ & 1 & 1 & 1 \\
Marcks & $7.9 \%$ & $11.1 \%$ & $12.8 \%$ & 4 & 3 & 3 \\
Viva & $12.3 \%$ & $15.5 \%$ & $16 \%$ & 2 & 2 & 2 \\
Sariayu & $10.4 \%$ & $8.3 \%$ & $8.6 \%$ & 3 & 4 & 4 \\
Pixy & $5.2 \%$ & $6.8 \%$ & $5.7 \%$ & 5 & 5 & 5 \\
\hline
\end{tabular}

Sumber: Modifikasi www. topbrand-award.com

Berdasarkan pada Tabel 2 diatas, dapat dilihat

bahwa Perusahaan kosmetik di Indonesia, khususnya yang megeluarkan produk bedak padat 
diantaranya Pigeon, Marcks, Wardah dan Pixy. Penjualan bedak tabur brand Pixy mengalami penurunan pembelian, pembelian bedak tabur Pixy pada tahun 2015 sebanyak 5.2\%, mengalami kenaikan pada tahun 2016 sebanyak $1.6 \%$ dan pada tahun 2017 mengalami penurunan kembali sebanyak $1.1 \%$. Karena mempertahankan loyalitas serta meningkatkan jumlah transaksi menjadi tujuan utama bagi perusahaan (Razati \& Ruhimat, 2008).

Salah satu yang termasuk ke dalam industri kosmetik (industri produk perawatan pribadi) adalah Pixy yang mengeluarkan produk bedak tabur. Perusahaan kosmetik memerlukan tingkat keputusan pembelian yang tinggi karena memiliki dampak kepada citra merek, atribut produk dan minat pembelian kembali terhadap produk tersebut. Dampak pada perusahaan jika memiliki tingkat keputusan pembelian yang rendah akan menimbulkan penurunan pendapatan perusahaan dan konsumen akan berpindah kepada perusahaan lain sejalan dengan pendapat (Laios \& Moschuris, 2015).

Dengan demikian untuk mengatasi masalah keputusan pembelian berdasarkan beberapa penelitian yang dilakukan diantaranya 1) Faktor Pribadi, 2) Faktor Psikologis, dan 3) Faktor Sosial (Sangadji \& Sopiah, 2013:335). Fakor lain yaitu 1) usaha pemasaran perusahaan, dan 2) lingkungan sosial budaya (seperti: keluarga, sumber informal, sumber nun komersial yang lain, kelas sosial, sub budaya dan budaya) (L.G Schiffman \& Kanuk, 2007:443). Kepribadian merek sebagai ciri khas dan atribut produk seolah-olah itu mencerminkan seseorang (Solomon, Bamossy, Askegaard, \& Hogg, 2013:202).

Suatu merek yang sesuai dengan karakteristik konsumen akan memberikan kepercayaan terhadap merek tersebut. Indikator lain adalah sejauh mana tingkat kepentingan merek tersebut bagi seseorang berkenaan dengan aktivitas kepribadian mereka, misalnya manfaat atau kelebihan yang dimiliki dalam kaitan dengan penggunaannya (Yin \& Mansori, 2016).

Berdasarkan latar belakang masalah di atas, maka tujuan penelitian ini adalah untuk memperoleh hasil temuan mengenai: (1) gambaran kepribadian merek, dan (2) gambaran keputusan pembelian.

\section{KAJIAN PUSTAKA}

Pemasaran selama ini dikenal sebagai aktivitas yang tidak terpisahkan dari dunia bisnis, fungsinya yang sangat penting bagi keberlangsungan hidup sebuah perusahaan yaitu memastikan adanya pertukaran nilai antara perusahaan dengan konsumennya. Pemasaran dalam perkembangannya memiliki peranan besar dalam membentuk pola persaingan, orientasi bisnis perusahaan, bahkan cara-cara sebuah bisnis dijalankan dalam sebuah industri (Kartajaya, 2010:2). Pemasaran mencakup kegiatan yang amat luas dan meliputi segala akitivitas perusahaan untuk mengetahui serta memenuhi kebutuhan dan keinginan masyarakat melalui suatu proses penciptaan, penawaran dan pertukaran produk berupa barang dan jasa (Razati \& Ruhimat, 2008).

Konsep pemasaran sebenarnya secara sederhana sebagai usaha untuk mempertemukan barang dan jasa yang dihasilkan oleh perusahaan kepada konsumen untuk memenuhi kebutuhan dan keinginan, sehingga kepuasan tercapai (Rampl \& Kenning, 2014). Pemasaran adalah suatu proses sosial yang didalamnya individu dan kelompok mendapatkan apa yang mereka butuhkan dan inginkan dengan menciptakan, menawarkan, dan secara bebas mempertukarkan produk yang bernilai dengan pihak lain ( $\mathrm{P}$ Kotler, Keller, Brady, Goodman, \& Hansen, 2012).

Pemasaran strategis merupakan proses pengembangan marketing strategy proses, dengan mempertimbangkan lingkungan bisnis yang terus berubah sesuai dengan kebutuhan pelanggan dan bertujuan untuk memberikan nilai yang unggul. Fokus pemasaran strategis lebih berpusat pada kinerja organisasi dibandingkan usaha untuk meningkatkan penjualan. Pemasaran strategis menghubungkan organisasi dengan lingkungan dan memandang pemasaran sebagai tanggung jawab dari keseluruhan bisnis tersebut (Cravens \& Piercy, 2013). Strategic brand management melibatkan desain dan implementasi program pemasaran serta kegiatan untuk membangun, mengukur, dan mengelola ekuitas merek (Keller, 2013:58). Langkah utama dalam strategic brand management yaitu : 1) Identifying and developing brand plans, 2) Designing and implementing brand marketing programs, 3) Measuring and interpreting brand performance, dan 4) Growing and sustaining brand equity (Keller, 2013).

Salah satu proses dalam pemasaran strategis yaitu brand resonance and the brand value chain yang mengacu pada cara membuat intens, aktif hubungan kesetiaan dengan pelanggan. Model ini mempertimbangkan bagaimana positioning merek mempengaruhi bagaimana konsumen berpikir, 
merasa, dan sejauh mana mereka beresonansi atau terhubung dengan merek. Sedangkan brand value chain adalah sarana di mana pemasar dapat melacak penciptaan nilai proses untuk merek mereka untuk lebih memahami dampak keuangan dari pengeluaran pemasaran mereka dan investasi (Keller, 2013). Strategi pemasaran menerapkan strategi brand building blocks, proses pembentukan merek yaitu : 1) brand salience, 2) brand feelings, 3) brand imagery, 4) brand performance, dan 5) brand judgement (Keller, 2013).

Brand imagery melibatkan empat langkah, Langkah ke tiga yaitu membangun dan mengelola merek program pemasaran yang dilakukan yaitu melalui brand personality and values. Merek merupakan harta tidak berwujud yang berperan penting bagi perusahaan karena dapat membawa beberapa keuntungan serta merupakan dasar dari keunggulan kompetitif perusahaan (Arora \& Neha, 2016). Kepribadian merek terbentuk pada setiap aspek dari suatu merek yang dapat digunakan oleh konsumen untuk menyimpulkan kepribadian merek.

Dalam penelitian ini dimensi yang digunakan adalah lima indikator menurut (Keller, 2013) yaitu: 1) Sincerity (ketulusan) yaitu karakter yang jujur, rendah hati dan sederhana. Sincerity ada dalam kejujuran dalam kualitas dari produk, keaslian dan keidentikan suatu merek dengan sifat-sifat yang sederhana.

2) Excitement (semangat) mengartikan karakter yang dinamis dan penuh semangat dan imajinasi yang tinggi dalam melakukan perbedaan dan inovasi.

3) Competence (kemampuan) mengartikan kemampuan yang dapat diandalkan dan dapat dipercaya oleh pelanggannya.

4) Sophistication (keduniawian) mengartikan karakteristik yang berkaitan dengan ekslusifitas yang dibentuk oleh keunggulan prestige, citra merek maupun tingkat daya tarik mempesona.

5) Ruggedness (ketangguhan) mengartikan karakteristik merek yang dikaitkan dengan manfaat suatu merek dalam menunjang kegiatan luar rumah dan kekuatan atau daya tahan dari produk tersebut.

Sebuah merek kemudian harus memiliki karakteristik tertentu. Merek harus dikenal karena sesuatu, dihubungkan dengan sesuatu. Hal ini berkaitan dengan positioning merek tersebut di benak pelanggan. Banyak riset yang ditujukan untuk menentukan bagaimana posisi suatu merek dibandingkan posisi merek pesaingnya dalam hal sesuatu yang dianggap sebagai karakteristik merek yang menonjol (Mulyadi \& Saktiawati, 2008). Meski terdapat banyak aspek apapun dari program pemasaran yang dapat mempengaruhi kepribadian merek, pemasaran komunikasi dan periklanan dapat sangat berpengaruh karena kesimpulan konsumen membuat tentang pengguna yang mendasari atau situasi penggunaan yang digambarkan atau tercermin dalam iklan (Keller, 2013).

Konsumen sering memilih dan menggunakan merek yang memiliki kepribadian merek yang konsisten dengan merek mereka konsep diri sendiri (Keller, 2013). Dalam pandangan ini, konsumen dengan tenang dan hati-hati mengintegrasikan sebanyak mungkin informasi mungkin dengan apa yang sudah mereka ketahui tentang suatu produk, dengan susah payah menimbang plus dan minus dari setiap alternatif, dan tiba pada keputusan yang memuaskan (Blackwell, 2005:259). Dalam hal ini tentunya bisa meliputi nama, gambar/logo, serta slogan tertentu yang digunakan para pelaku pasar untuk mempromosikan produk-produknya dan brand awareness, yang berkaitan dengan kemampuan untuk mengenali atau mengingat merek (Dirgantari, 2016).

Perilaku konsumen terjadi dalam empat kategori atau jenis situasi yang luas: situasi komunikasi, situasi pembelian, situasi penggunaan, dan disposisi situasi (Hawkins, 2010). Keputusan Pembelian dapat diartikan sebagai tahapan dimana pembeli telah menentukan pilihannya dan melakukan pembelian produk, serta mengkonsumsinya (Suharno, 2010). Pemasar harus memahami kebutuhan dan keinginan pelanggan tentang merek untuk mengembangkan strategi pemasaran karena keputusan pembelian merupakan hal penting dalam perilaku konsumen. Kesesuaian antara diri dan kepribadian merek secara positif mempengaruhi merek kesetiaan secara langsung dan tidak langsung melalui keserasian fungsional, produk keterlibatan dan kualitas hubungan merek.

Ini mendukung yang terpenting pentingnya kongruensi diri-merek, tidak hanya dalam pertempuran untuk menarik dan menarik untuk kelompok konsumen tertentu, tetapi juga untuk pengasuhan jangka panjang hubungan merekkonsumen, loyalitas merek-konsumen, dan dalam upaya menciptakan kepribadian merek yang tepat (Heding, Knudtzen, \& Bjerre, 2009). Keputusan konsumen tidak hanya berfokus pada atribut merek tetapi lebih pada perasaan atau emosi yang terkait dengan memperoleh atau menggunakan merek atau dengan situasi di mana produk dibeli atau digunakan (Hawkins, 2010).

Keputusan pembelian memiliki urutan langkah-langkah yang terdiri dari proses pengambilan keputusan, dimulai dengan masalah 
pengakuan dan diakhiri dengan hasil (Noel, 2009). terdapat lima tahap yang dilewati pembeli untuk mencapai keputusan pembelian, yaitu pengambilan keputusan terdiri dari pengenala kebutuhan, pencarian informasi, evaluasi alternatif, keputusan pembelian dan tingkah laku pasca pembelian (Keller \& Kotler, 2016).

Konsumen mendasarkan evaluasi awal mereka pada nilai yang diketahui dan kemudian menyesuaikan evaluasi mereka berdasarkan informasi tambahan yang tersedia seperti saran dari teman, ulasan, atau bahkan pengalaman hasil (Noel, 2009). Terdapat lima dimensi yang membangun keputusan pembelian yaitu : 1) brand choice (Pilihan merek)., 2) dealer (penyalur), 3) timing (waktu), 4) quantity (kuantitas) dan 5) payment method (metode pembayaran) (Keller \& Kotler, 2016:198). Membangun sebuah keputusan pembelian yang positif dalam menjaga hubungan jangka panjang antara perusahaan dan pelanggan menjadi faktor penting untuk menciptakan kepribadian merek.

Kepribadian merek dapat menjadi variabel berguna dalam menganalisis konsumen, pilihan merek dan merek juga memiliki kepribadaian dan konsumen cenderung memilih merek yang sesuai dengan kepribadian mereka (Keller \& Kotler, 2016). Hubungan kepribadian merek terhadap keputusan pembelian sangatlah erat. Ini dikarenakan kepribadian merek menjadi salah satu proses yang menentukan dalam pembelian konsumen terhadap produk atau jasa. Apabila kepribadian merek sesuai dengan kepribadian konsumen dan dapat memberikan nilai yang sesuai maka akan timbul rasa percaya pada diri konsumen terhadap produk tersebut dan konsumen akan memilih produk tersebut karena sesuai dengan karkteristik konsumen tersebut.

Kepribadian merek dapat digunakan untuk membedakan suatu merek dalam kategori produk dan memberikan karakteristik yang dapat digunakan untuk memasarkan suatu merek. Ini dikembangkan dan didefinisikan oleh pengiklan dengan harapan bahwa konsumen akan mengaitkan merek mereka dengan kata sifat atau gambar spesifik, ketika membeli sebuah merek, konsumen membeli makna simbolik yang terkait dengan produk di samping produk fisik yang intinya, mereka membeli gambar kecil yang mereka rasa melekat pada produk (Guthrie, Hye-shin, \& Jaehee, 2007).

Berdasarkan penjelasan mengenai pengaruh kepribadian merek terhadap keputusan pembelian maka disusun sebuah paradigma pengaruh kepribadian merek terhadap keputusan pembelian secara jelas digambarkan dalam Gambar 2 sebagai berikut:

\begin{tabular}{|c|c|c|}
\hline $\begin{array}{c}\text { Kepribadian } \\
\text { Merek }\end{array}$ & $\rightarrow \begin{array}{c}\text { Keputusan } \\
\text { Pembelian }\end{array}$ \\
\cline { 1 - 1 } & & $\begin{array}{c}\text { Brand choice } \\
\text { Dealer } \\
\text { Excerity } \\
\text { Competence } \\
\text { Sophistication } \\
\text { Ruggedness }\end{array}$ \\
Quantity \\
Payment Method
\end{tabular}

\section{GAMBAR 2 PARADIGMA PENELITIAN}

\section{METODE PENELITIAN}

Penelitian ini dilakukan untuk mengetahui pengaruh kepribadian merek terhadap keputusan pembelian pada konsumen yang membeli produk bedak tabur Pixy di Indonesia. Penelitian ini akan diuji mengenai kebenaran hipotesis melalui pengumpulan data dilapangan, atas pengaruh kepribadian merek terhadap keputusan pembelian pada produk kosmetik bedak tabur Pixy. Adapun yang menjadi objek penelitian sebagai variabel $\mathrm{X}$ atau variabel bebas (independent variabel) adalah kepribadian merek dengan dimensinya yang mencakup sincerity, excitement, competence, sophistication dan ruggedness. Masalah penelitian yang merupakan variabel $(\mathrm{Y})$ atau variabel terikat (dependent variabel) adalah keputusan pembelian dengan dimensinya yang mencakup brand choice, dealer, timing, quantity dan payment method.

Sumber data penelitian merupakan sumber data yang diperlukan dalam kegiatan penelitian. Data dibedakan menjadi dua, yaitu data primer dan data sekunder.

TABEL 3 JENIS DAN SUMBER DATA

\begin{tabular}{llcc}
\hline No & \multicolumn{1}{c}{ DATA } & $\begin{array}{l}\text { JENIS } \\
\text { DATA }\end{array}$ & \multicolumn{1}{c}{ SUMBER DATA } \\
\hline 1 & $\begin{array}{l}\text { TopBrands } \\
\text { Konsumen } \\
2\end{array}$ & Sekunder & www.topbrand-award.com \\
& $\begin{array}{l}\text { Pixy } \\
\text { kosmetik } \\
\text { Komunitas } \\
\text { Pixy }\end{array}$ & Sekunder & Konsumen Pixy kosmetik \\
& Sekunder & $\underline{\text { YIndonesiaOfficial/commu }}$ \\
& & $\underline{\text { nity }}$ \\
\hline
\end{tabular}

Sumber: Hasil Pengolahan Data 2018

Objek atau unit analisis pada penelitian ini yaitu konsumen yang membeli produk bedak tabur Pixy di Indonesia. Penelitian ini dilakukan dalam kurun waktu kurang dari satu tahun, maka 
pendekatan yang digunakan adalah metode cross sectional method, dimana penelitian ini dengan cara mempelajari objek dalam kurun waktu tertentu atau tidak berkesinambungan dalam jangka waktu panjang.

Penelitian deskriptif adalah penelitian yang dilakukan untuk mengetahui nilai variabel mandiri, baik satu variabel atau lebih (independent) tanpa membuat perbandingan atau menghubungkan antara satu dengan variabel yang lain (Sugiyono, 2010:11). Penelitian deskriptif disini bertujuan untuk memperoleh deskripsi atau gambaran secara keseluruhan mengenai kepribadian merek terhadap keputusan pembelian pada produk kosmetik bedak tabur Pixy. Berdasarkan tingkat penjelasan dan bidang penelitian, maka jenis penelitian ini adalah penelitian deskriptif dan verifikatif, dengan metode penelitian yang digunakan adalah explonatory survey. Populasi dalam penelitian ini adalah konsumen yang mengikuti facebook Pixy berukuran 364.150 anggota berdasarkan pengikut pada facebook Pixy Indonesia.

Teknik penarikan sampel yang digunakan dalam penelitian ini adalah teknik penelitian populasi atau sensus, karena sampel diambil dari seluruh populasi yang dinamakan sampel jenuh. Simple Random Sampling merupakan teknik profitability yang diketahui dan setara untuk diteliti (Malhotra, 2010:382). Penelitian ini menggunakan simple random sampling agar terdapat sampel yang representative.

Adapun rumus yang digunakan untuk mengambil suatu sampel dari sebuah populasi ialah dengan menggunakan rumus Harun Al Rasyid (Alrasyid, 1994:44). Sedangkan $\mathrm{n}_{0}$ dapat dicari dengan menggunakan rumus sebagai berikut:

$$
n_{0}=\left[\frac{Z\left(1-\frac{\alpha}{2}\right) S}{\delta}\right]^{2}
$$

Keterangan:

$$
\begin{aligned}
& \mathrm{N} \quad=\text { Populasi } \\
& \mathrm{n} \quad=\text { Banyaknya sampel yang diambil dari } \\
& \text { seluruh unit } \\
& \mathrm{S} \quad=\text { Simpangan baku untuk variabel yang } \\
& \text { diteliti dalam populasi dengan menggunakan } \\
& \text { Deming's Emperical Rule }
\end{aligned}
$$$$
\delta=\text { Bound of error yang bisa ditolerir atau }
$$
dikehendaki sebesar 5\%

Adapun perhitungan ukuran sampel yang dipergunakan dalam penelitian ini adalah dengan mencari nilai $\mathrm{n}_{\mathrm{o}}$ lebih dahulu, yaitu:

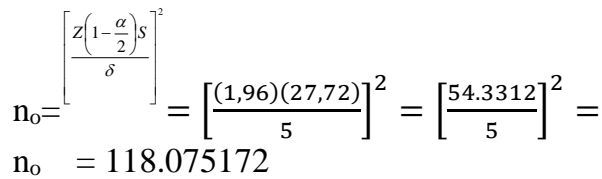

Nilai $\mathrm{n}_{\mathrm{o}}$ sudah diketahui yaitu sebesar $\mathrm{n}_{0}$ 118.075172 , setelah itu kemudian dilakukan penghitungan untuk mencari nilai $\mathrm{n}$ untuk mencari jumlah sampel yang akan diteliti. Setelah itu kemudian dilakukan penghitungan untuk mencari nilai $\mathrm{n}$ untuk mencari jumlah sampel yang akan diteliti.

$$
\begin{aligned}
& \mathrm{n}=\frac{\boldsymbol{n}_{\mathbf{0}}}{\mathbf{1 + \frac { \boldsymbol { n } _ { \mathbf { 0 } } } { \boldsymbol { N } }}} \\
& \mathrm{n}=\frac{118,075172}{\mathbf{1 +} \frac{\mathbf{1 1 8 , 0 7 5 1 7 2}}{364150}} \\
& \mathrm{n}=\frac{118,075172}{\mathbf{1 . 0 3 4 2}} \\
& \mathrm{n}=114.17054 \\
& \mathrm{n} \approx 115 \text { (dibulatkan) }
\end{aligned}
$$

Berdasarkan perhitungan diatas, maka ukuran sampel minimal dalam penelitian ini ditetapkan dengan $\alpha=0.05$ diperoleh ukuran sampel (n) minimal sebanyak hasil dari $\mathrm{n}$ orang. Baiknya sampel selalu ditambah sedikit lagi dari jumlah matematik untuk jaminan agar sampel yang digunakan menjadi representatif (Surakhmad, 2004:100), maka pada penelitian ini ditambah 15 responden sehingga jumlah sampel yang dibutuhkan berukuran 130 .

Teknik pengumpulan data yang digunakan adalah studi kepustakaan, studi lapangan dengan penyebaran kuesioner, dan studi literature. Sedangkan teknik analisis data yang dilakukan adalah analisis deskriptif menggunakan distribusi frekuensi.

Secara statistik, hipotesis yang akan diuji dalam rangka pengambilan keputusan penerimaan atau penolakan hipotesis dapat dirumuskan sebagai berikut:

1. $H_{0}: \rho \leq 0$ yang berarti bahwa tidak terdapat pengaruh antara kepribadian merek terhadap keputusan pembelian.

$\mathrm{H}_{\mathrm{a}}: \rho>0$ yang berarti bahwa terdapat pengaruh antara kepribadian merek terhadap keputusan pembelian.

\section{HASIL PENELITIAN DAN PEMBAHASAN Gambaran Kepribadian Merek}

Kepribadian merek adalah suatu gabungan dari sifat manusia yang dapat diterapkan pada suatu merek (Keller \& Kotler, 2016). Kepribadian merek menciptakan sebuah dasar hubungan antara konsumen dan perusahaan atau organisasi (Jafarnejad et al., 2012 dalam (Karjaluoto, Munnukka, \& Salmi, 2016). Persepsi merek adalah sikap, perspektif, dan pandangan yang dimiliki 
konsumen terhadap abrik. Berbagai sifat tentang merek dapat memengaruhi perkembangan sikap merek positif (Guthrie et al., 2007).

Variabel kepribadian merek terdiri dari lima dimensi dengan 15 indikator. Dimensi pertama yaitu Sincerity dengan indikator karakter yang jujur dalam kualitas produk, keaslian dan keidentikan suatu merek dengan sifat-sifat yang sederhana. Dimensi kedua yaitu excitement dengan indikator yang penuh semangat dan imajinasi yang tinggi dalam melakukan perbedaan dan inovasi. Dimensi ketiga yaitu competence dengan indikator Kemampuan yang mencakup sifat seperti cerdas, aman dan dapat dipercaya oleh pelanggan. Dimensi keempat yaitu sophistication dengan indikator kebanggaan yang dirasakan pelanggan, citra merek kosmetik dan daya tarik produk. Dimensi kelima yaitu ruggedness dengan indikator karakteristik merek yang dikaitkan dengan manfaat suatu merek dalam menunjang kegiatan luar rumah dan kekuatan atau daya tahan produk.

Hasil pengolahan data mengenai kategori variabel kepribadian merek terlihat pada Gambar 2 berikut ini:

Gambar 3. Garis Kontinum Kepribadian Merek

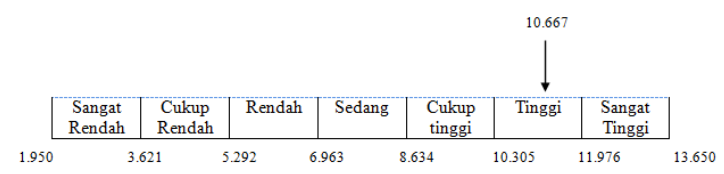

Sumber : Hasil Pengolahan Data, 2018

\section{GAMBAR 3 \\ GARIS KONTINUM VARIABEL KEPRIBADIAN MEREK}

Berdasarkan hasil penelitian dari kuesioner yang disebar kepada 130 responden dapat diketahui bahwa kepribadian merek bedak tabur Pixy di Indonesia mendapatkan skor 10.667 atau $78 \%$ dari skor ideal yaitu 13.650. Perolehan skor tersebut secara kontinum berada pada kategori baik dengan interval antara 10.305 dan 11.976. Dengan hasil perolehan nilai ini dapat disimpulkan bahwa bedak tabur Pixy di Indonesia, penciptaan kepribadian merek sudah menunjukkan kinerja yang diharapkan walaupun belum optimal, mengingat begitu pentingnya kepribadian merek dalam menunjang perilaku positif dari konsumen.

TABEL 4

REKAPITULASI TANGGAPAN KONSUMEN MENGENAI KEPRIBADIAN MEREK

\begin{tabular}{lllll}
\hline No & Dimensi & Skor & Skor & Persentase\% \\
\cline { 5 - 5 }
\end{tabular}

\begin{tabular}{llccc}
\hline & & Total & Rata-rata & \\
\cline { 1 - 1 } \cline { 5 - 5 } 2 & Sincerity & 2806 & 2666.75 & 77.09 \\
2 & Excitement & 2091 & 3556 & 76.59 \\
3 & Competence & 2158 & 3556 & 79.05 \\
4 & Sophistication & 2140 & 3556 & 78.39 \\
5 & Ruggedness & 1472 & 3556 & 80.88 \\
\hline & Total & $\mathbf{1 0 . 6 6 7}$ & $\mathbf{1 6 . 8 8 9}$ & $\mathbf{7 8 \%}$ \\
\hline
\end{tabular}

Sumber: Hasil Pengolahan Data 2018

Apabila dilihat dari Tabel 3 dapat diketahui bahwa skor tertinggi terdapat pada dimensi ruggedness sebesar $80.88 \%$ dengan total skor sebanyak 1.472 hal tersebut dikarenakan konsumen manfaat dari produk yang mampu mendukung aktivitas diluar ruangan dan daya tahan dari produk bedak tabur Pixy. Sedangkan excitement memiliki skor terendah $76.59 \%$ dengan skor sebesar 2.091 disebabkan karakter penuh semangat dan imajinasi yang tinggi dalam melakukan perbedaan dan inovasi tidak sesuai dengan yang dirasakan konsumen.

Hal ini sesuai dengan penelitian terdahulu yang mengemukakan bahwa di antara karakteristik yang terkait dengan produk, bahwa jenis kemasan, harga, atribut dan kategori produk dan bahkan kelas sosial ekonomi yang dirasakan dari produk dapat mempengaruhi kepribadiannya, karena penggunaan dan pengalaman dengan merek memberi konsumen kenangan yang menyenangkan dan meningkatkan ekuitas merek, dan karena kepribadian merek dibentuk oleh pengalaman konsumen dengan merek dan oleh iklan (Orozoco-Gomez \& Toldos-Romeo Ma, 2015).

Kognitif melibatkan cara berpikir kreatif pelanggan dan mereproduksi hal dengan cara yang berbeda. Respon kognitif konsumen terhadap merek menyebabkan konsumen akan berpikir atau merasa ingin tahu tentang aspek-aspek dalam merek, seperti konsumen akan merasa ingin tahu tentang makna di balik desain atau logo suatu merek (Kwong \& Candinegara, 2014).

Aaker (1997) dalam (Guthrie et al., 2007) memberikan banyak implikasi untuk penelitian kepribadian merek. Pertama, agar merek menjadi sukses, kepribadiannya harus sesuai dengan kepribadian konsumen saat ini atau yang ideal. Ini dapat dilakukan dengan mengidentifikasi dimensi merek yang mendeskripsikan merek, dan memastikan kepribadian dimensi ini cukup dilabeli 
kepada konsumen. Tujuan utamanya adalah untuk memastikan kepribadian merek memengaruhi preferensi konsumen terhadap suatu merek dalam kategori produk tertentu.

\section{Gambaran Keputusan Pembelian}

Keputusan pembelian didefinisikan sebagai proses integrasi dimana pengetahuan dikombinasikan untuk mengevaluasi dua atau lebih perilaku alternative dan memilih salah satu (Peter \& Jerry, 2008). Keputusan pembelian adalah suatu keputusan yang dilakukan oleh konsumen yang dipengaruhi oleh kebudayaan, kelas social, keluarga dan referensigrup yang akan membentuk suatu sikap pada diri individu kemudian melakukan pembelian (Buchari Alma, 2008).

Variabel keputusan pembelian terdiri dari lima dimensi dengan 7 indikator. Dimensi pertama yaitu brand choice dengan indikator ketertarikan terhadap produk kosmetik, pembelian produk kosmetik atas dasar kepercayaan terhadap bahan yang digunakan dan pembelian berdasarkan popularitas merek kosmetik. Dimensi kedua yaitu dealer dengan indikator kemudahan akses tempat pembelian kosmetik. Dimensi yang ketiga yaitu timing dengan indikator waktu pembelian produk kosmetik sesuai kebutuhan. Dimensi ke empat yaitu quantity dengan indikator pembelian didasarkan pada banyaknya produk kosmetik yang dibeli. Dimensi ke lima yaitu pament method dengan indikator kemudahan dalam melakukan transaksi pembayaran di gerai kosmetik tersebut.

Hasil pengolahan data mengenai kategori variabel kepribadian merek terlihat pada Gambar 3 berikut ini :

Gambar 4. Garis Kontinum Keputusan Pembelian

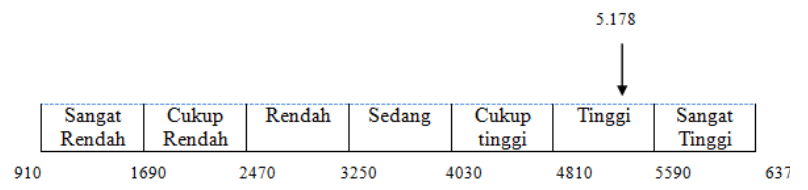

Sumber : Hasil Pengolahan Data, 2018

\section{GAMBAR 4 \\ GARIS KONTINUM VARIABEL KEPUTUSAN PEMBELIAN}

Berdasarkan hasil penelitian dari kuesioner yang disebar kepada 130 responden dapat diketahui bahwa keputusan pembelian bedak tabur Pixy di Indonesia mendapatkan skor 5.178 atau 74,91\%, dari skor ideal yaitu 6.370. Perolehan skor tersebut secara kontinum berada pada kategori cukup baik dengan interval antara 4.810 dan 5590.

Keputusan pembelian menjadi hal yang penting karena perspektif pengambilan keputusan menggabungkan ekonomi dalam pendekatan informasi untuk proses pencarian; itu mengasumsikan konsumen akan mengumpulkan data sebanyak mungkin untuk kebutuhan membuat keputusan (Lamb \& Hair, 2011). Pilihan merek merupakan kegiatan dimana konsumen memilih atau memutuskan merek mana yang akan dibeli, setiap merek memiliki ciri-ciri tersendiri, perusahaan harus dapat mengetahui bagaimana konsumen akan memilih merek (Keller \& Kotler, 2016:198).

TABEL 5

REKAPITULASI TANGGAPAN KONSUMEN MENGENAI KEPUTUSAN PEMBELIAN

\begin{tabular}{llccc}
\hline No & Dimensi & $\begin{array}{c}\text { Skor } \\
\text { Total }\end{array}$ & $\begin{array}{c}\text { Skor } \\
\text { Rata-rata }\end{array}$ & Persentase\% \\
\hline 1 & Brand Choice & 2170 & 1726 & 79 \\
2 & Dealer & 728 & 5178 & 80 \\
3 & Timing & 687 & 5178 & 75.49 \\
4 & Quantity & 735 & 5178 & 80.77 \\
5 & Payment Method & 858 & 5178 & 94.29 \\
\hline & Total & $\mathbf{5 . 1 7 8}$ & $\mathbf{2 2 . 4 3 8}$ & $\mathbf{8 2 \%}$ \\
\hline
\end{tabular}

Sumber: Hasil Pengolahan Data 2018

Apabila dilihat dari Tabel 5 dapat diketahui bahwa skor tertinggi terdapat pada dimensi payment method dengan presentase sebesar $94,29 \%$ dengan skor sebesar 858. Sedangkan tanggapan yang terendah adalah pada dimensi timing dengan presentase sebesar 75,49\% dengan skor sebesar 687 dari total seluruh dimensi. Dimensi payment method memiliki skor tertinggi dikarenakan konsumen memiliki ketertarikan terhadap cara dalam melakukan transaksi pembayaran yang mudah. Sedangkan timing memiliki skor terendah disebabkan pembelian bedak tabur tidak dapat dilakukan sesering mungkin karena merupakan barang yang bisa dipakai berkali-kali.

Teknik analisis regresi linear sederhana mengenai pengaruh kepribadian merek terhadap keputusan pembelian, perlu dilakukan uji asumsi klasik pada penelitian ini. Uji normalitas pada penelitian ini mengunakan rumus KolmogrovSmirnov dengan bantuan software SPSS 23.0 for windows. Hasil uji normalitas dengan KolmogrovSmirnov Z Test diperoleh nilai KSZ, sebesar 0,072 
Asymp.Sig sebesar 0.094 atau > 0,05 maka dapat disimpulkan daa tersebut berdistribusi normal. Setelah melakukan dua kali uji normalitas dengan metode yang berbeda-beda maka lebih memperkuat bahwa data hasil penelitian itu benar-benar berdistribusi normal.

Pengujian lienaritas ini digunakan untuk mengetahui adanya hubungan linearitas antar variabel kepribadian merek terhadap keputusan pembelian. Berdasarkan hasil pengujian menggunakan uji $\mathrm{F}_{\text {test }}$ didapatkan $\mathrm{F}_{\text {hitung }}$ sebesar 96.083 dengan tingkat signifikansi $0,000 \leq 0,05$ artinya variabel kepribadian merek (X) secara keseluruhan model tersebut sudah fit dan terdapat hubungan antara variabel kepribadian merek terhadap keputusan pembelian sehingga regresi bisa dipakai untuk memprediksi keputusan pembelian konsumen. berdsarkan hasil pengujian linearitas, maka dapat dikatakan bahwa data yang dihasilkan memenuhi asumsi Linearitas.

Hasil pengujian titik terpencil, dapat diketahui bahwa titik tersebut bukan merupakan titik terpencil, karena hasil $t_{\text {hitung }}$ menunjukkan nilai yang lebih kecil daripada $t_{\text {tabel }}(-0,968<1,656)$. Sehingga, kriteria yang digunakan atas hasil perhitungan tersebut adalah terima $H_{0}$ yang artinya titik yang mencurigakan tidak dianggap sebagai titik terpencil dan tidak perlu dikeluarkan.

Dengan mengunakan SPSS (Statistical Product and Service Solution) 23.0 for windows, diperoleh hasil koefisien regresi. Berdasarkan nilai konstanta dan nilai koefisien regresi linear sederhana untuk variabel bebas. Berdasarkan nilainilai itu maka dapat ditentukan model regresi linear sederhana yang dinyatakan dalam bentuk persamaan sebagai berikut:

$$
\begin{gathered}
\mathbf{Y}=\mathbf{a}+\mathbf{b X} \\
\mathrm{Y}=7,665+0,395 \mathrm{X}
\end{gathered}
$$

Berdasarkan persamaan regresi linear sederhana di atas, nilai konstanta sebesar 7,665 menyatakan bahwa jika tidak ada kepribadian merek, maka besarnya keputusan pembelian sebesar 7,665. Koefisien regresi pada variabel kepribadian merek sebesar 0,395 menyatakan bahwa setiap penambahan nilai kerja kepribadian merek akan terjadi peningkatan keputusan pembelian sebesar 0,395. Sebaliknya jika terjadi penurunan keputusan pembelian, kepribadian merek akan menurunkan keputusan pembelian sebesar 0,395 satu satuan nilai. Dapat dikatakan bahwa kepribadian merek yang dibangun perusahaan akan berpengaruh terhadap tingkat pembelian konsumen.

Berdasarkan niali signifikasi : dari tabel Coefficients diperoleh nilai sebesar $0,000<0,05$.
Sehingga dapat disimpulkan bahwa variabel kepribadian merek (X) berpengaruh terhadap variabel keputusan pembelian (Y). Dari hasil penghitungan koefisien determinasi untuk kepribadian merek (X) terhadap keputusan pembelian (Y) adalah 43\%. Dengan kata lain keputusan pembelian dipengaruhi $42,6 \%$ oleh kepribadian merek sedangkan $57,4 \%$ oleh faktorfaktor lainnya diluar kepribadian merek. Berikut ini rekapitulasi kepribadian merek terhadap keputusan pembelian.

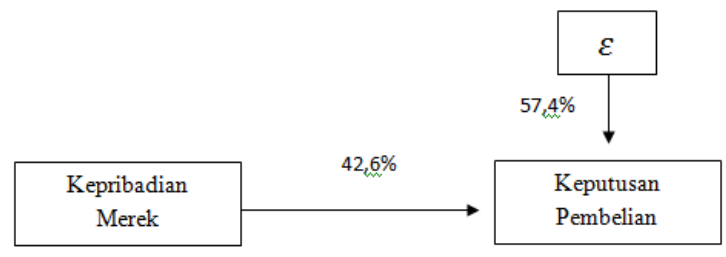

Sumber: Hasil Pengolahan Data 2018

\section{GAMBAR 5 \\ PENGARUH KEPRIBADIAN MEREK TERHADAP KEPUTUSAN PEMBELIAN}

Uji keberartian koefisien regresi dilakukan melalui uji t dengan cara membandingkan antara $t$ hitung dengan $t$ tabel dari koefisien regresi variabel independen. Sebagaimana uji t bertujuan untuk mengetahui apakah koefisien regresi dari tiap variabel independen memiliki pengaruh yang berarti terhadap variabel dependen. Hasil uji t dijelaskan pada Tabel 6 sebagai berikut

\section{TABEL 6}

HASIL UJI T KEPRIBADIAN MEREK TERHADAP KEPUTUSAN PEMBELIAN

\begin{tabular}{|c|c|c|c|c|c|c|}
\hline & \multirow{2}{*}{ Model } & $\begin{array}{r}\text { Unstanc } \\
\text { Coeff }\end{array}$ & $\begin{array}{l}\text { ardized } \\
\text { ients }\end{array}$ & $\begin{array}{c}\text { Standardized } \\
\text { Coefficients }\end{array}$ & \multirow{2}{*}{$\mathrm{T}$} & \multirow{2}{*}{ Sig. } \\
\hline & & $\mathrm{B}$ & $\begin{array}{l}\text { Std. } \\
\text { Error }\end{array}$ & Beta & & \\
\hline \multirow[t]{2}{*}{1} & (Constant) & 7.665 & 3.302 & & 2.321 & .022 \\
\hline & $\begin{array}{l}\text { Kepribadian } \\
\text { Merek }\end{array}$ & .395 & .041 & .653 & 9.746 & .000 \\
\hline
\end{tabular}
Coefficients $^{\mathrm{a}}$

a. Dependent Variable: Keputusan Pembelian

Sumber: Hasil Pengolahan Data 2018

Berdasarkan Tabel 8 diketahui niali $t$ hitung sebesar 9,746 > tabel 1,656 sehingga dapat disimpulkan bahwa $\mathrm{H}_{0}$ ditolak dan $\mathrm{H}_{\mathrm{a}}$ diterima yang artinya Terdapat pengaruh positif antara kepribadian merek $(X)$ terhadap keputusan pembelian (Y) pada konsumen yang membeli bedak Tabur Pixy di Indonesia.

Pengujian hipotesis yang menggunakan regresi linear sederhana, regresi tersebut ditunjukkan dengan benar perubahan keputusan pembelian (Y) yang terjadi mengikuti perubahan kepribadian merek $(\mathrm{X})$ yaitu sebesar 9,746. Artinya 
bahwa jika tidak ada kinerja kepribadian merek $(\mathrm{X}=0)$ maka keputusan pembelian 9,746 satu satuan nilai. Koefisien regresi 0,395 satu satuan nilai artinya setiap terjadi peningkatan kepribadian merek akan meningkatkan keputusan pembelian konsumen sebesar 0,395 satu satuan nilai, dan sebaliknya jika terjadi penurunan kepribadian merek akan menurunkan keputusan pembeliankonsumen sebesar 0,395 satu satuan nilai $(\mathrm{Y}=9,746+0,395 \mathrm{X})$ dimana koefsien determinasi (KD) yaitu dengan menguadratkan koefisien kolerasi yang diperoleh hasil sebesar $42,6 \%$. Ini berarti penerapan kepribadian merek dapat mempengaruhi keputusan pembelian konsumen sebesar $42,6 \%$.

Hasil ini memberikan bukti bahwa setiap merek kosmetik memiliki ciri kepribadian merek yang diidentifikasi oleh konsumen. Meskipun kompetensi kepribadian merek mungkin merupakan ciri universal yang diinginkan dalam merek kosmetik dengan kepribadian lainnya berbeda. Seorang konsumen mengevaluasi upaya yang diperlukan untuk membuat yang khusus pilihan, dan kemudian dia memilih strategi yang paling sesuai dengan tingkat upaya yang diperlukan (Blackwell, 2005:259). Pemasar dapat memainkan peran dalam mengarahkan konsumen tentang kriteria mana yang harus digunakan sebagai atribut penentu. Keputusan tentang atribut yang digunakan adalah hasil dari pembelajaran prosedural, di mana seseorang mengalami serangkaian langkah kognitif sebelum membuat pilihan. Langkah-langkah ini termasuk mengidentifikasi atribut penting, mengingat apakah merek yang bersaing berbeda pada atribut-atribut itu, dan seterusnya (Solomon et al., 2013).

\section{KESIMPULAN}

Berdasarkan hasil penelitian di pembahasan dikemukakan kesimpulan sebagai berikut:

Gambaran mengenai kepribadian merek dapat dilihat dari dimensi-dimensinya yang terdiri dari sincerity, excitement, competence, sophistication dan ruggedness berada pada kategori baik. Hal ini menunjukan bahwa kepribadian merek yang dirasakan konsumen bedak tabur Pixy dapat dikatakan baik secara keseluruhan. Dimensi yang memperoleh tanggapan yang paling tinggi yaitu dimensi ruggednes, sedangkan dimensi dengan perolehan tanggapan paling rendah adalah dimensi excitement. Gambaran mengenai keputusan pembelian pada konsumen yang membeli bedak tabur Pixy dapat dilihat dari dimensi-dimensinya yang terdiri dari brand choice, dealer, timing, quantity dan payment method berada pada kategori baik. Hal ini menunjukan bahwa kondisi keputusan pembelian yang dimiliki Pixy sudah menunjukkan kinerja yang cukup. Dimensi yang memperoleh tanggapan paling tinggi adalah dimensi payment method dan dimensi dengan perolehan tanggapan paling rendah adalah timing.

Adanya penelitian ini diharapkan dapat membantu peneliti berikutnya dalam melakukan penelitian mengenai kepribadian merek dan keputusan pembelian dengan menggunakan indikator yang berbeda dari sumber teori yang lebih beragam, dan terhadap objek yang berbeda, karena masih banyaknya keterbatasan dalam penelitian ini, khususnya yang berkaitan dengan metode penelitian dan teknik pengumpulan data. Brand personality merupakan langkah penting jika kita mengakui bahwa pelanggan mengembangkan hubungan dengan merek. Pada kenyataannya, kita cenderung mengembangkan hubungan sejati dengan merek yang memiliki karakteristik sama dengan seseorang. Kita semua memiliki merek yang selalu kita pakai dan pakai lagi, yang telah kita pakai selama bertahun-tahun dan mendefinisikan siapa kita ini. Penelitian ini diharapkan dapat membantu perusahaan untuk memperhatikan langkah-langkah melakukan analisis kondisi kepribadian merek dan keputusan pembelian agar dapat mengoptimalkan kinerjanya. Perusahaan dapat dengan mudah mengidentifikasi merek yang paling sukses dalam kategori produk, mempelajari kepribadian mana yang disampaikan merek ini, dan menyalin atau menyesuaikan strategi pemasaran mereka untuk merebut segmen pasar yang sama dan / atau lainnya (Guthrie et al., 2007).

Indikator dari kepribadian merek yang paling rendah adalah tingkat excitement perusahaan harus mampu mengembangkan aspek excitement agar mendapatkan respon yang baik dari para konsumen. Beberapa strategi yang dapat dilakukan diantaranya kemasan yang digunakan dibuat lebih kreatif, memiliki berbagai pilihan, serta proses dalam mengembangakan produk secara cepat.

Indikator dari keputusan pembelian yang paling rendah adalah aspek timing. Untuk meningkatkan timing perusahaan dapat memberikan potongan harga agar konsumen membeli bedak tabur Pixy. Konsumen merespons pengaruh pemasaran dan situasi serentak. Untuk memahami perilaku konsumen, kita harus tahu tentang konsumen, tentang objek stimulus utama, seperti produk atau iklan yang menjadi konsumen merespons, dan tentang situasi di mana respons tersebut terjadi (Hawkins, 2010).

Berdasarkan penelitian diatas menyatakan bahwa semakin baik kepribadian merek, maka 
semakin baik pula keputusan pembelian pada konsumen bedak tabur Pixy di Indonesia, selain itu, semakin buruk kepribadian merek, maka semakin buruk pula keputusan pembelian pada konsumen bedak tabur Pixy di Indonesia. Hasil penelitian penulis diharapkan mampu memberikan sumbangan ilmiah bagi pengembangan ilmu manajemen pemasaran, khususnya pemasaran produk dan pengembangan merek dan juga sebagai masukan yang konstruktif dan inspiratif bagi para manajer merek (brand manager) dalam mempertahankan dan meningkatkan kualitas dari produk dan mereknya untuk tetap bertahan.

\section{DAFTAR PUSTAKA}

Aaker, J. L. (1997). Dimensions of brand personality. Journal of Marketing Research, 347.

Al-rasyid, H. (1994). Teknik Penarikan Sampel dan Penyusunan Skala. Bandung: Universitas Padjajaran.

Arora, S., \& Neha. (2016). Determinants of Customer-based Brand Equity: A Study of Public and Private Banks. Global Business Review, 17(4), 905-920. Retrieved from http://doi.org/10.1177/0972150916645693

Blackwell, R. D. (2005). Consumer Behaviour. Mason: Permissions Department.

Buchari Alma. (2008). Mnajemen Pemasaran dan Pemasaran Jasa. Bandung: Alfabeta.

Cravens, \& Piercy. (2013). Strategic Marketing (10th ed.) (10th ed). New York: Mc Graw Hil.

Dirgantari, P. D. (2016). PERANAN BAURAN PEMASARAN JASA PENDIDIKAN TERHADAP UPAYA MENINGKATKAN EKUITAS MEREK BERBASIS PELANGGAN PERGURUAN TINGGI (STUDI PADA PERGURUAN TINGGI DI JAWA BARAT). Jurnal Pendidikan Manajemen Bisnis, 11, 22-31.

Guthrie, M., Hye-shin, K., \& Jaehee, J. (2007). The effects of facial image andcosmetic usage on perceptions ofbrand personality. Journal of Fashion Marketing and Management, 12(2), 164-181. http://doi.org/10.1108/13612020810874863

Hawkins, D. I. (2010). Building Marketing Strategy Consumer Behavior.

Heding, T., Knudtzen, C. F., \& Bjerre, M. (2009). Brand Management.

Hegner, S. M., Jevons, C., Hegner, S. M., \& Jevons, C. (2016). Brand trust: a cross-national validation in Germany, India , and South Africa. http://doi.org/10.1108/JPBM-02-
2015-0814

Karjaluoto, H., Munnukka, J., \& Salmi, M. (2016). Article information: Journal of Service Theory and Practice, 26(1).

Kartajaya, H. (2010). Perjalanan Pemikiran Konsep Pemasaran Hermawan Kertajaya. Jakarta: Penerbit Erlangga.

Keller, K. L. (2013). Strategic Brand Management (4th ed.). England: Pearson Education Inc. Retrieved from http://doi.org/10.2307/1252315

Keller, K. L., \& Kotler, P. (2016). Marketing Management (15e ed.). England: Pearson Education Limited.

Kotler, P., Keller, K., Brady, M., Goodman, M., \& Hansen, T. (2012). Marketing management. England: Pearson Education Limited.

Kotler, P., \& Keller, K. L. (n.d.). Marketing Management.

Kwong, M. Z., \& Candinegara, I. (2014). elationship between Brand Experience, Brand Personality, Consumer Satisfaction , and Consumer Loyalty of DSSMF Brand. iBuss Management, 2(2), 89-98.

Laios, L. G., \& Moschuris, S. J. (2015). The influence of enterprise type on the purchasing decision process. International Journal of Operations \& Production Management.

Lamb, C. W., \& Hair, J. F. (2011). Marketing.

Malhotra, N. K. (2010). Marketing Research (6th ed.). United States of America.

Mulyadi, H., \& Saktiawati, D. (2008). Pengaruh Brand Personality terhadap Loyalitas Pelanggan Sampo Sunsilk. Jurnal Pendidikan Manajemen Bisnis, 7.

Noel, H. (2009). Consumer behaviour. Switzerland: AVA Publishing SA.

Orozoco-Gomez, M., \& Toldos-Romeo Ma, M. de 1 P. (2015). Brand personality and purchase intention, 27(5), 462-467. http://doi.org/10.1108/EBR-03-2013-0046

Peter, J. P., \& Jerry, C. O. (2008). Consumer Behaviour perilaku konsumen dan strtegi pemasaran. Jakarta: Erlangga.

Rampl, L. V., \& Kenning, P. (2014). Employer brand trust and affect: linking brand personality to employer brand attractiveness. http://doi.org/http://doi.org/10.1108/EJM-022012-0113

Ratih, H., \& Irna, W. (2008). pengaruh pemasaran eksperiensial terhadp retensi pelanggan pada pengunjung resort \& spa kampung sampireun garut. Jurnal Pendidikan Manajemen Bisnis, 7, 1-19.

Razati, G., \& Ruhimat, R. (2008). pengaruh sales 
promotion terhadap keputusan pengguna kartu kredit bni. Pendidikan Manajemen Bisnis, 7.

Sangadji, E. M., \& Sopiah. (2013). Perilaku Konsumen Pendekatan Praktis Disertai Himpunan Jurnal Penelitan. Yogyakarta: Andi offset.

Schiffman, L. ., \& Kanuk, L. L. (2007). Consumer Behaviour. New Jersey: Pearson Prestice Hall.

Solomon, M. R., Bamossy, G., Askegaard, S., \& Hogg, M. K. (2013). Consumer Behaviour.

Sugiyono. (2010). Metode Penelitian Bisnis. Bandung: Alfabetha.

Suharno. (2010). Marketing in Practice (edisi pert). Yogyakarta: Graha Ilmu.
Surakhmad, W. (2004). Pengantar Penelitian Ilmiah Dasar Metode Teknik. Bandung: Tarsito.

Utama, D. H., \& Amelia, F. (2009). ENGARUH ATRIBUT PRODUK TERHADAP KEPUASAN PELANGGAN PRODUK TEH CELUP SOSRO DAN 2 TANG (Survei Pada Pelanggan Teh Celup di Griya Pahlawan dan Giant Pasteur Bandung). Urnal Pendidikan Manajemen Bisnis, 8(30-40).

Yin, C., \& Mansori, S. (2016). Factor that influences consumers ' brand loyalty towards cosmetic products. Journal of Marketing Management and Customer Behavior, 1, 1229. 